УДК 371. 13: 37. 046. 12

DOI: $10.15330 /$ esu. 1.147-153
Тамара Марчій-Дмитраи, кандидат педагогічних наук, доцент, ДВНЗ “Прикарпатський національний університет імені Василя Стефаника" (м. Івано-Франківськ, Україна) Tamara Marchii-Dmytrash, Candidate of pedagogical sciences (PhD), Associate Professor, Vasyl Stefanyk Precarpathian national university (Ivano-Frankivsk, Ukraine) tamara.dmytrash@ukr.net

\title{
СУЧАСНИЙ СТАН РЕАЛЗАЦЇ ПРИНЦИПУ НАСТУПНОСТІ У ПДГОТОВЦІ ДІТЕЙ ДОШКІЛЬНОГО ВІКУ ДО НАВЧАННЯ В ШКОЛІ
}

\author{
THE CURRENT STATE OF IMPLEMENTATION OF THE PRINCIPLE OF \\ CONTINUITY IN PREPARING CHILDREN FOR SCHOOL
}

У статті обтрунтовано сучасний стан реалізачії принципу наступності $у$ підготовиі дітей до навчання в иколі. Акцентовано на важливості особистісного розвитку дитини, зосередженості навчально-виховного прочесу на потребах їі навчания і вихования. Конкретизовано і розмежовано поняття "підготовка до школи", “готовність до иколи" mа "икільна зрілість". Визначено, ио однісю з важливих якостей педагога в контексті реалізачії принчипу наступності є вміння діагностувати - доброзичливо, иілеспрямовано, виоірково спостерігати за дитиною у різних видах діяльності, використовуючи індивідуальні навчальні, ігрові завдання, в яких будуть проявлятися спечифічні риси ї особистості (навчальні уміння, мотивачія, витривалість, пам'ять, самоорганізація, креативний підхід до вирімення завдань), а також узагальнювати факти, нагромаджувати й аналізувати дитячі роботи упродовж тривалого часу.

Ключові слова: принцип наступності, заклад доикільної освіти, початкова икола, дитина дошкільного віку, молодиии иколяр, підготовка до навчання в школі, икільна зрілість, готовність до навчання в иколі.

The current state of implementation of the principle of continuity in preparing children for school is substantiated in the article. Emphasis is placed on the value of the child's personal development, the focus of the educational process on the needs of its education and upbringing. The concepts of "school preparation", "school readiness" and "school maturity" are specified and delineated.

It is substantiated that openness, flexibility, plasticity of the older preschool child's psychics provides great internal opportunities for positive changes before a difficult stage in her life - schooling, and therefore - early adolescence, so primary school teacher must be well trained psychologically. If the load, the content of the education, the requirements do not meet the capacity of children, there are risk factors. If at one age the normal conditions of development are disturbed, then the next one has to solve two tasks at the same time: training and correction.

It is determined that one of the important qualities of the teacher in the context of the implementation of the principle of continuity is the ability to diagnose - kindly, purposefully, selectively observe the child in different activities, using individual educational, play tasks, which will show specific traits of the child's personality (her teaching skills, motivation, endurance, 
memory, self-organization, creative approach to solving problems), as well as to summarize facts, to accumulate and analyze children's works for a long time.

Particular attention in the implementation of the principle of continuity deserves to create for preschoolers and primary school pupils a developmental environment that will contribute to the development of cognitive activity, creativity, independence, in particular through the usage of attributes for different games, creating toys, arranging a book corner with cognitive content literature, the usage of cards, globe, various schemes and more.

Key words: continuity principle, institution of preschool education, primary school, preschool child, junior schoolchild, preparation for schooling, school maturity, readiness for schooling.

Актуальність дослідження. Аналізуючи сучасний стан реалізації принципу наступності у підготовці дітей до навчання в школі, слід ураховувати той факт, що учнями першого класу початкової школи стають як діти шостого, так і сьомого року життя. Різниця у віці - всього рік. Але шестирічні за своїм психічним розвитком дошкільники, i провідна діяльність у них - гра, а семирічні - молодші школярі, $\mathrm{i}$ провідна діяльність у них - навчальна. Для дітей шестирічного віку (навіть якшо вони стали першокласниками) провідним видом діяльності залишається гра. Саме вона зумовлює найважливіші зміни в житті на етапі навчання. Функція гри полягає не лише в оволодінні правилами та нормами життя, пізнанні стосунків, ролей, функцій людей, а й у самопізнанні, усвідомленні свого внутрішнього світу, оволодінні саморегуляцією. Крім того, в ній виникають і диференціюються нові види діяльності, зокрема, учіння, яке готує перехід індивіда до нової, вищої стадії розвитку. Шестирічна дитина в силу функціональної специфіки не може жити без активності, без гри. Зупинити ігрову діяльність і в примусовому порядку включити малюка в іншу, що суперечить спрямованості внутрішніх сил означає загальмувати інтенсивний розвиток $\mathrm{i}$ всебічне розкриття його задатків, тому місце гри в психічному розвитку дітей цього вікового періоду важко переоцінити.

Натомість дітей 7-го року життя уже не так захоплюють прості ігри та іграшки. Вони більшою мірою виявляють здібності до розумових та вольових зусиль. У них підвищується допитливість, інтерес до знань і розумової діяльності, 3'являється вимогливість до себе та інших. Діяльність керується ієрархічною системою мотивів. Розвивається об'єктивна самооцінка і самосвідомість взагалі, з'являється довільність моральної саморегуляції, виникають первинні етичні інстанції.

Якщо дошкільна освіта якісно змінилась в контексті постановки і реалізації завдань підготовки дітей до школи відповідно до їх вікових можливостей, то освітня діяльність початкової школи на сучасному етапі базується на реалізації принципу наступності, згідно 3 яким у ній мають створюватись умови для подальшого повноцінного розвитку надбань вихованців, здобутих у дошкільному дитинстві, i водночас для формування новоутворення молодшого шкільного віку - навчальної діяльності як провідної.

У зв'язку з цим метою статті $\epsilon$ проаналізувати стан реалізації принципу наступності у підготовці дітей до навчання в школі в сучасних ЗДО і школах I ступеня.

Аналіз наукових досліджень. Проведений нами аналіз психолого-педагогічної літератури щодо специфіки підготовки дітей до навчання в школі в контексті реалізації принципу наступності виявив неоднозначність щодо розуміння в науковому обігу понять "підготовка дітей до школи", “підготовленість" і “готовність” в їх змістовому і структурному аспектах. 
Так, у контексті обгрунтування проблем підготовки до школи проаналізовано як психофізіологічні особливості розвитку дітей дошкільного віку (“шкільна зрілість”), так і передумови їнього успішного навчання в школі (Л. Божович, В. Давидов, О. Дусавицький, Д. Ельконін, О. Запорожець, Г. Цукерман), а також напрями роботи, які забезпечують наступність і перспективність підготовки дітей у ЗДО і першому класі школи I ступеня (Л. Артемова, А. Богуш, Л. Калмикова, Н. Кічук, М. Львов, Н. Шиліна та ін.).

Різними вченими досліджено сутність і структуру готовності дітей до шкільного навчання (О. Венгер, Н. Гуткіна, В. Котирло, О. Кравцова, В. Мухіна, К. Поліванова, О. Проскура, Н. Шиліна та ін.); уточнено мету та зміст підготовки дітей до систематичного навчання в школі (Р. Афанасьєва, А. Богуш, Н. Бібік, Е. Вільчковський, Р. Жуковська, Л. Кочина, Н. Кудикіна, Л. Пеньєвська, З. Плохій та ін.).

У працях вітчизняних дослідників (А. Богуш, В. Котирло, Я. Котлярова, С. Ладивір, О. Проскура, Н. Шиліна) підкреслено, що готовність до навчання в школі - це багатокомпонентне цілісне утворення, інтегральна характеристика особистості, яка містить психологічний, морфологічний, інтелектуальний, мотиваційний, емоційновольовий, комунікативно-мовленнєвий компоненти і формується вкінці дошкільного дитинства. Підготовка дітей до школи дозволяє перейти від ігрової діяльності до навчальної й успішно засвоїти ії зміст; це цілісна система.

Термін "наступність у навчанні" вперше було теоретично обгрунтовано в працях Е.Баллера, Г.Ісаєнка, пізніше він став об'єктом різних досліджень, зокрема таких педагогів і психологів, як Л. Артемової, О. Богданової, З. Борисової, А. Леушиної, Г. Люблінської, С. Рубінштейна, О.Савченко, В. Сухомлинського, $€$. Тіхєєвої, О. Усової та інших. Деякі дисертації присвячено проблемам реалізації принципу наступності дошкільної та початкової освіти в контексті вивчення певної навчальної дисципліни: математики (І. Попова, Р. Руга), рідної мови (Л. Калмикова та інші), природознавства (Т. Ковальчук, Н. Лисенко, Д. Струннікова та ін.), напрямків виховання: трудового (Л. Дашковська), естетичного (А. Ароніна), морального (О. Ткаченко).

Таким чином, проблема формування готовності дітей до навчання в школі залишається актуальною. Необхідність їі вивчення випливає з реалій життя. Поперше, підвищились вимоги до рівня знань дітей, які вступають до шшколи. По-друге, впровадження в початкову школу нових програм, різноманітних інновацій передбачає підготовку дошкільників із урахуванням сучасних технологій.

Виклад основного матеріалу. У інструктивно-методичних рекомендаціях щодо забезпечення наступності дошкільної та початкової освіти (додаток до листа МОН України від 19.04.2018 р.) акцентовано на необхідності організації освітнього процесу на принципах наступності й перспективності задля забезпечення гармонійного розвитку особистості, що має на меті єдність в координації мети, змісту, методів, форм щодо організації процесу навчання дітей шести-семирічного віку [1].

Згідно з вимогами Базового компонента дошкільної освіти кожна дитина повинна здобути відповідну підготовку до навчання в школі. Організація такої підготовки $є$ як науковою, так і нормативною проблемою. У попередньому досвіді (3 80-х років XX століття) найбільш оптимальна форма ії розв'язання - створення підготовчих груп при школах.

За Базовим компонентом дошкільної освіти у центрі навчально-виховного процесу ЗДО - дитина, яка повинна гармонійно розвиватися у сферах "Я та інші люди”, “Я і природа”, “Я і суспільство”. Це дозволяє опосередковано впливати на 
різні види діяльності, щоб позитивно впливати на мовлення, розвиток уяви i мислення, просторових уявлень дітей тощо. Тобто йдеться про відхід від предметоцентризму та формування цілісного погляду на використання можливостей різних сфер діяльності дошкільнят 3 метою їх соціалізації, емоційного та мовленнєвого розвитку, самореалізації тощо.

Сучасна початкова освіта, на відміну від інших тї рівнів, є досить варіативною. Вона може забезпечуватися через різні типи навчальних закладів, зокрема: 1) дошкільний заклад-початкова школа; 2) автономна початкова школа 3 повним складом класів; 3) малокомплектна початкова школа; 4) класи-комплекти у складі школи другого i другого-третього ступенів; 5) початкова ланка у складі спеціалізованих шкіл, гімназій, ліцеїв, навчально-виховних комплексів; 6) початкова школа для дітей-інвалідів у домашніх умовах тощо. Очевидно, що й надалі варіативність початкової освіти зберігатиметься й удосконалюватиметься.

Останнім часом у центрі діяльності як дошкільної, так і шкільної освіти цінність особистісного розвитку дитини, зосередженість навчально-виховного процесу на потребах іiі навчання i виховання. Таким чином, традиційний функціональний підхід змінився на педоцентричний, в основі якого - повноцінність проживання індивідом кожного вікового етапу.

Більше 20 років назад, коли розпочалося експериментальне навчання 6-річних дітей і поступовий перехід до чотирьохрічної початкової школи, воно стало новацією в освітній системі. Тому до цих змін влада, педагогічна, психологічна i медична науки ставилися 3 винятковою увагою як до події загальнодержавного значення. Відбулася перевірка і удосконалення матеріальної бази початкових шкіл, диспансеризація дітей, чітке комплектування перших класів, підвищення рівня кваліфікації учителів, випуск нових підручників і посібників. Сьогодні активно реформуються всі рівні освіти, до того ж цей процес здійснюється в умовах нестабільного і обмеженого фінансування і складної економічної ситуації в країні.

Разом 3 тим, перехід до масової чотирьохрічної школи відбувся в умовах кризи системи дошкільної освіти. В наш час простежується суперечність між законодавчою i науково-методичною готовністю закладів дошкільної освіти повноцінно розв'язувати проблеми дошкілля і неможливістю це реалізувати через економічні, соціальні та інші проблеми розвитку держави. Проблеми наступності і перспективності вказаних вище ланок з кожним роком стають гострішими.

У шкільному середовищі сильною є тенденція трактувати наступність “згоривниз", коли ЗДО, на думку багатьох педагогів, мав би перетворитися на "мінішколу". Це нераціональна позиція, розрахована на швидкий, нестійкий ефект. Поширена й інша тенденція - головне, щоб до початку навчання в школі дитина була самостійною, активною, розкутою. Правомірною є позиція тих психологів i педагогів, які розуміють наступність як двобічний процес, коли зберігається самоцінність дошкільного дитинства і створюються передумови для успішного формування навчальної діяльності першокласників. Початкова ланка, спираючись на досягнення дошкільного віку, має підхопити, зміцнити, розвинути накопичене до школи і на цьому грунті формувати новоутворення молодшого шкільного віку.

У реальній практиці часто не простежується розмежування понять “підготовка до школи", “готовність до школи" та “шкільна зрілість”.

Підготовка до школи передбачає загальну і спеціальну. Перша - це фізична, мотиваційна, інтелектуальна, емоційно-вольова, соціальна готовність, а друга готовність засвоювати предметні знання, уміння, навички. 
Інтегративним результатом цих напрямків діяльності $€$ готовність дитини до навчання у школі, яка формується у неї після завершення дошкільного дитинства i сприяє успішній адаптації до умов i вимог шкільного навчання. Ступенем сформованості мотиваційної, розумової, емоційно-вольової і соціальної готовності $\epsilon$ перехід дитини до навчальної діяльності, iї позитивне ставлення до школи, взаємини з учителем та учнями.

Щодо шкільної зрілості, то їі часто розуміють як оволодіння уміннями, знання, здібностями, мотивацісю та іншими необхідними для оптимального рівня засвоєння шкільної програми поведінковими характеристиками, досягнення такого рівня розвитку, коли дитина стає здатною брати участь у шкільному навчанні.

Педагогові слід розуміти, що першокласники дуже відрізняються від учнів 3-4 класів і тому слід аналізувати методичні надбання, “приміряти" напрацьоване до нових умов, тому що кожна дитина має своє індивідуальне світосприйняття та різні рівні готовності до засвоєння конкретного матеріалу, а мислення дошкільнят у своєму розвитку проходить наочно-дійову, наочно-образну 3 елементами словеснологічного мислення стадії. Якщо ж ще у дошкільному віці проводити навчання за типом шкільного, яке опирається переважно на словесно-логічне, то притаманне дошкільникам образне, конкретно-емоційне мислення повною мірою може не розвинутися.

У молодшому шкільному віці з'являється мотивація до навчання, дошкільна допитливість переходить в елементарні пізнавальні інтереси, розвивається самооцінка, критичність до себе і оточення, удосконалюються навички спілкування. Принципово важливо, що діти оволодівають повноцінними навичками читання, письма, обчислень, це засвідчує їхнє пізнавальне і соціальне зростання [3].

Відкритість, гнучкість, пластичність психіки дитини старшого дошкільного віку унікальні. Психологи відзначають, що вона дає великі внутрішні можливості для позитивних змін. Щоб використати цей потенціал без шкоди, а навпаки, зберегти і зміцнити дитячу особистість перед складним етапом в іiі житті - раннім підлітковим віком, вчитель початкової школи має бути добре підготовленим психологічно. Не предметоцентризм, а дитиноцентризм - так можна окреслити особливість сучасних методик і обов'язкове врахування принципу наступності у навчально-виховній роботі.

Якщо навантаження, зміст навчання, вимоги не відповідають можливостям вихованців, виникають фактори ризику. На жаль, поширена тенденція до надто раннього початку навчання дітей, зокрема, читати чи писати, ще до навчання в школі.

Психологи зауважують, що у випадку, якщо на одному віковому етапі порушуються нормальні умови розвитку, то на наступному доводиться одночасно розв'язувати вже два завдання: навчання і корекції. Тому так важливо створити сприятливу атмосферу для навчання саме в той час, коли діти відкриті для впливів педагога iз урахуванням принципу наступності та індивідуального розвитку особистості. Це гуманно щодо вихованців і оптимально щодо організації навчальновиховного процесу.

Дбаючи про здоров'я дітей, варто пам'ятати про те, що їхня фізична і психічна втомлюваність залежить також від посильності та обсягу завдань, емоційного та фізичного комфорту, відчуття особистої захищеності.

Головне - не нашкодити здоров'ю дітей, завжди правильно оцінювати їхні реальні можливості. 
На особливу увагу в реалізації принципу наступності заслуговує створення для дошкільнят $\mathrm{i}$ молодших учнів розвивального середовища, яке сприятиме розвитку пізнавальної активності, креативності, самостійності. Так, використовуючи атрибути до різних ігор, створюючи ігротеки, облаштовуючи книжковий куточок 3 літературою пізнавального змісту, застосовуючи у процесі взаємодії 3 дітьми карти, глобус, різноманітні схеми тощо, педагог має можливість якомога ефективніше використовувати можливості середовища [2, с. 197].

У цьому контексті однією з важливих якостей педагога $є$ вміння діагностувати - це не споглядання, а доброзичливе, цілеспрямоване, вибіркове спостереження за дитиною у різних видах діяльності. Мається на увазі використання на практиці різних видів індивідуальних навчальних, ігрових завдань, в яких будуть проявлятися специфічні риси дитячої особистості (ії навчальні уміння, мотивація, витривалість, пам'ять, самоорганізація, креативний підхід до вирішення завдань), а також узагальнення фактів, нагромадження й аналіз дитячих робіт упродовж тривалого часу.

Так, навчання формує особистість, але значно глибше, системніше виховує організація життєдіяльності. Це поле впорядкованої свободи дитини, коли вона виховується вільною, але з почуттям відповідальності і любові до рідного краю, 3 використанням індивідуального підходу, і разом 3 тим підготовленою до життя серед людей.

В умовах реалізації реформи освіти зазнає радикальних змін і початкова школа. Наймолодшим школярам уперше в житті надається не лише право, а й обов'язок учитися, тобто займатися діяльністю, яка має соціальне значення. Нова соціальна позиція і навчальна діяльність дітей розвиваються настільки, наскільки вони стають предметом їх власних потреб і інтересів, змістом "внутрішньої позиції".

Висновки i перспективи дослідження. Підсумовуючи сказане вище, констатуємо, що для даних вікових мікроперіодів дитинства характерні істотні психологічні відмінності в мотиваційній сфері. Ці відмінності конкретно виявляються у ставленні вихованців до школи, навчальних предметів, педагога. Наприклад, позитивне ставлення до уроків трудового навчання та образотворчого мистецтва у шестиліток пояснюється тим, що вони зацікавлені самою роботою (особливість, характерна для дошкільників, виявляється в грі, де основне значення має процес, а не результат). На уроках трудового навчання та образотворчого мистецтва діяльність семиліток розгорнута у зовнішньому практичному плані $\mathrm{i}$ очевидним тут є зв'язок самої роботи і результату.

Отже, вікові відмінності у формуванні в дітей ставлення до школи, навчання, вчителя, своєрідність емоційної сфери шестиліток і семиліток є тією об'єктивною психологічною реальністю, на основі якої має бути побудовано педагогічний процес.

Перспективи подальших досліджень вбачаємо в обгрунтуванні адаптації дітей шостого і сьомого років до школи, доопрацювання потребує питання ефективності і доцільності реалізації принципу наступності на всіх етапах навчання в школі. Залишаються актуальними питання забезпечення співпраці ЗДО і ЗОШ I ступеня та належної методичної роботи з педагогами обох ланок освіти.

\section{Література}

1. Інструктивно-методичні рекомендації щодо забезпечення наступності дошкільної та початкової освіти. Додаток до листа МОН України від 19.04.2018 № 1/9-249. URL: http: // mon.gov.ua/storage/app/media/doshkilna/nastupnist/recomendazii.doc.

2. Садова Т. Пізнавальна активність як умова формування інтелектуальної готовності дошкільників до шкільного навчання. Гуманізація навчально-виховного процесу. Збірник 
наукових праць (спецвипуск): матеріали Всеукраїнської науково-практичної конференції "Реалізація принципу наступності дошкільної та початкової ланок у контексті суб'єктної парадигми освіти”. 17-18 травня 2007 року / за заг. ред. проф. В. Сипченка. Слов'янсык: Видавничий центр СДПУ, 2007. $415 \mathrm{c}$.

3. Формування мотивів навчання. URL: http: // www.info-library.com.ua/books-text-4277.html.

\section{References}

1. Instruktyvno-metodychni rekomendatsii shchodo zabezpechennia nastupnosti doshkilnoi ta pochatkovoi osvity. Dodatok do lysta MON Ukrainy vid 19.04.2018 № 1/9-249. URL: http: // mon.gov.ua/storage/app/media/doshkilna/nastupnist/recomendazii.doc.

2. Sadova T. Piznavalna aktyvnist yak umova formuvannia intelektualnoi hotovnosti doshkilnykiv do shkilnoho navchannia. Humanizatsiia navchalno-vykhovnoho protsesu. Zbirnyk naukovykh prats (spetsvypusk): materialy Vseukrainskoi naukovo-praktychnoi konferentsii "Realizatsiia pryntsypu nastupnosti doshkilnoi ta pochatkovoi lanok u konteksti subiektnoi paradyhmy osvity". 17-18 travnia 2007 roku / za zah. red. prof. V. Sypchenka. Sloviansk: Vydavnychyi tsentr SDPU, 2007. $415 \mathrm{~s}$.

3. Formuvannia motyviv navchannia. URL: http: // www.info-library.com.ua/books-text-4277.html

Одержано статтю: 9.10.2019

Прийнято до друку: 31.10.2019

УДК $376-056.36$

DOI: $10.15330 /$ esu. $1.153-159$

\section{Наталія Матвеєва,}

кандидат педагогічних наук, доцент, ДВНЗ "Прикарпатський національний університет імені Василя Стефаника" (м. Івано-Франківськ, Україна)

Nataliia Matveieva, Candidate of pedagogical sciences $(\mathrm{PhD})$, Associate Professor, Vasyl Stefanyk Precarpathian National university (Ivano-Frankivsk, Ukraine) nataliematveieva@gmail.com

\section{ЧИННИКИ ВПЛИВУ НА МОВЛЕННЕВІ ПОРУШЕННЯ У ДІТЕЙ МОЛОДШОГО ШКІЛЬНОГО ВІКУ}

\section{THE FACTORS OF THE IMPACT ON SPEECH DISORDERS IN PRIMARY SCHOOL CHILDREN}

Н.Матвеєва наголоиуе на тому, що мова забезпечуе потреби особистості у спілкуванні, ознайомленні з навколиинім світом, нормами взасмодій між людьми, реалізацій власних задумів та потреб. У статті проаналізовано основні чинники впливу на появу поруиень мовлення $у$ дітей. Автор розглядае різні аспекти проблеми виникнення мовленнсвих порушень, а саме: біологічний, сочіально-психологічний, педагогічний. Актуалізуеться необхідність родинного виховання на усталених традиціях украйнського народу, збережения звичайв та морально-етичних чінностей, які загалом дозволяють розвинути мовлення особистості на відповідному рівні. Стаття розкриває основні вимоги Державного стандарту щодо навчания осіб із поруиениями мовления, а також визначас чіткі завдання задля підвищення ефективності та якості навчання учнів.

Ключові слова: спілкування, мовлення, мова, сочіалізація, розвиток, мовленнєвві порушення, корекиія, успішність.

The article analyzes the main factors influencing the occurrence of speech disorders in children. The author examines various aspects of the problem of speech disorders, namely: biological, socio-psychological, pedagogical. Particular attention should be paid to the assessment of individual factors that provoke the appearance of different types of speech impairment at an early age. In the article the necessity of family education on the established 